\title{
Design and Development of Rotary Power Weeder
}

\author{
Gatkal Narayan Raosaheb*, A.P. Petkar and S.H. Bhutada
}

Farm Machinery and Power Engineering, Aditya College of Agricultural Engineering and Technology, Beed, Maharashtra, India

*Corresponding author

\section{A B S T R A C T}

\section{Keywords}

Weeding efficiency, Field efficiency, Plant damage

\section{Article Info}

Accepted:

08 January 2020

Available Online:

10 February 2020
A rotary power weeder was designed and developed. The developed weeder consisted of frame, engine, tyne, wheel and handle. Weeding efficiency, field efficiency and plant damage of developed rotary weeder was $70.5 \%, 65 \%$ and $3.2 \%$, respectively. The fuel consumption and field capacity of developed rotary power weeder was $0.8 \mathrm{l} / \mathrm{h}$ and $0.09 \mathrm{ha} / \mathrm{h}$, respectively.

\section{Introduction}

Agriculture is the backbone of Indian economy. But weed is the measure problem for declining yield of crops day by day. A weed can be thought of as any plant growing in the wrong place at the wrong time. Weeding is an important but equally labor incentive agricultural unit operation. Weeding accounts for about $25 \%$ of the total labor requirement (900-1200 man $\mathrm{h} / \mathrm{ha}$ ) during a cultivation season, Silas et al., (2015).

In India, reduction in yield due to weed alone is estimated to be 16-42\% depending on crop and location and involves $1 / 3^{\text {rd. }}$ of the cost of cultivation Goel. et al., (2008). The weed should be controlled and eliminated at their early stage. Depending upon the weed density, 20-30 percent loss in grain yield is quite usual which might increase up to 80 per cent if adequate crop management practice is not observed. Delay and negligence in weeding operation affect the crop yield up to 30 to 60 percent Rajvir Yadav (2007). In India about 4.2 billion rupees are spent every year for controlling weeds in the production of major crops. At least 40 million tons of major food grains are lost due to weed, which were $11.8 \%$ of the total yield in Asia every year. Rajat (2017), Weeds accounts for about $50-70 \%$ reduction in yield. 
There are various weed control methods like mechanical, chemical, manual and weedicide. Mechanical weed control is very effective as compared to manual weeding it reduce drudgery, labour requirement and time. Mechanical weeding kills the weeds and also keeps the soil surface loose ensuring soil aeration and water intake capacity.

Hand weeding requires large labors and time compared to mechanical weed control. Chemical today the agricultural sector requires on-chemical weed control that ensures food safety. Consumers demand high quality food products and pay special attention to food safety. Physical weed control, such as precise inter - and intra-row weeder, it might be possible to control weeds in a way that meets consumer and environmental demands.

Weeder is mechanical device to remove the weeds from an agricultural land. A weeder may be manual or animal drawn and tractor mounted or power operated. It is used for intercultural operation in row crops. It is also suitable for gardens and orchard field.

\section{Materials and Methods}

\section{Component of developed rotary Power weeder}

\section{Frame}

$60 \mathrm{~cm}$ long iron angle are used for frame. 2HP power engine is mounted on frame fixed with $10 \mathrm{~mm} 4$ bolts. Overall dimension of frame is $60 \mathrm{cmsq} / \mathrm{ft}$ and width is $2 \mathrm{inch}$.

\section{Handle}

Handle is used for balancing rotary weeder in field operation. Round pipe is used for the handles with required dimensions \& Accelerator is fitted on handle \& connected to carburetor by using wire. The overall length of handle $1066 \mathrm{~mm}$ with two bends from point of attachment and have a height of 750 $\mathrm{mm}$ from ground level. The handle is attached on main frame at the rear of the machine with help of four pieces of nut and bolts of having diameter $10 \mathrm{~mm}$. With help of handle, the machine can be steered.

\section{Wheel}

It is used for transportation and operation in field. In the dry field condition the transport wheel is better for preventing the jerking in undulated fields and smooth field operation .The weeder is fitted with tyre sizes 22 to 28 inches $\left(560\right.$ to $710 \mathrm{~mm}$ ) diameter and $1^{1} / 2$ to 2 in $(38$ to $51 \mathrm{~mm})$ wide. The wheels are fitted on the wheel shaft .The wheel provides better traction and stability during dry field operation.

\section{Wheel shaft}

It is shaft on which wheels are mounted. Wheel shaft was selected as $90 \mathrm{~cm}$ long 4.5 $\mathrm{mm}$ wide wheel shaft is fitted the frame and engine load is mounted on the shaft.

\section{Tynes}

It is used for removing weeds in soil.

\section{Power requirement of weeder}

\section{Assumption}

Soil resistance has a considerable effect upon the power requirement of weeder. Also, width of cut and speed of operation influences power requirement of weeder. For calculating power requirement of the weeder,

Maximum soil resistance was taken as 0.6 $\mathrm{kgf} / \mathrm{cm}^{2}$.

The speed of operation of the weeder was considered as $1.5 \mathrm{~ms}^{-1}$ to $2.5 \mathrm{~ms}^{-1}$ 
Total width of coverage of rotary weeder of $40 \mathrm{~cm}$.

The depth of operation was considered as 3 to $5 \mathrm{~cm}$,

The width of coverage of rotary weeder $=$ Number of tyne $x$ distance covered by each tyne $=2 \times 20$

$=40$

Power requirement of weeder by (Sirmour, 2018)

$$
\begin{aligned}
& =\frac{0.652 .540}{75} \\
& =\quad 2.5 \mathrm{hp}
\end{aligned}
$$

So, $2.5 \mathrm{hp}$ petrol engine was selected
Where,

$\mathrm{Pd}=$ power requirement of rotary weeder

$\mathrm{SR}=$ soil resistence, $\mathrm{kg} / \mathrm{cm}^{2}$

$\mathrm{W}=$ Width od cut, $\mathrm{cm}$

$\mathrm{V}=$ speed of operation, $\mathrm{m} / \mathrm{s}$

\section{Chain length (Lc)}

The length of the chain is given by, (Sharma, D. 2013)
Where,

L $p=$ Chain length in pitches

$\mathrm{Cp}=$ center to center distance between sprockets in pitches

N1=No of teeth on smaller sprocket N2=Number of teeth on larger sprocket

\section{$15 \mathrm{~cm}$}
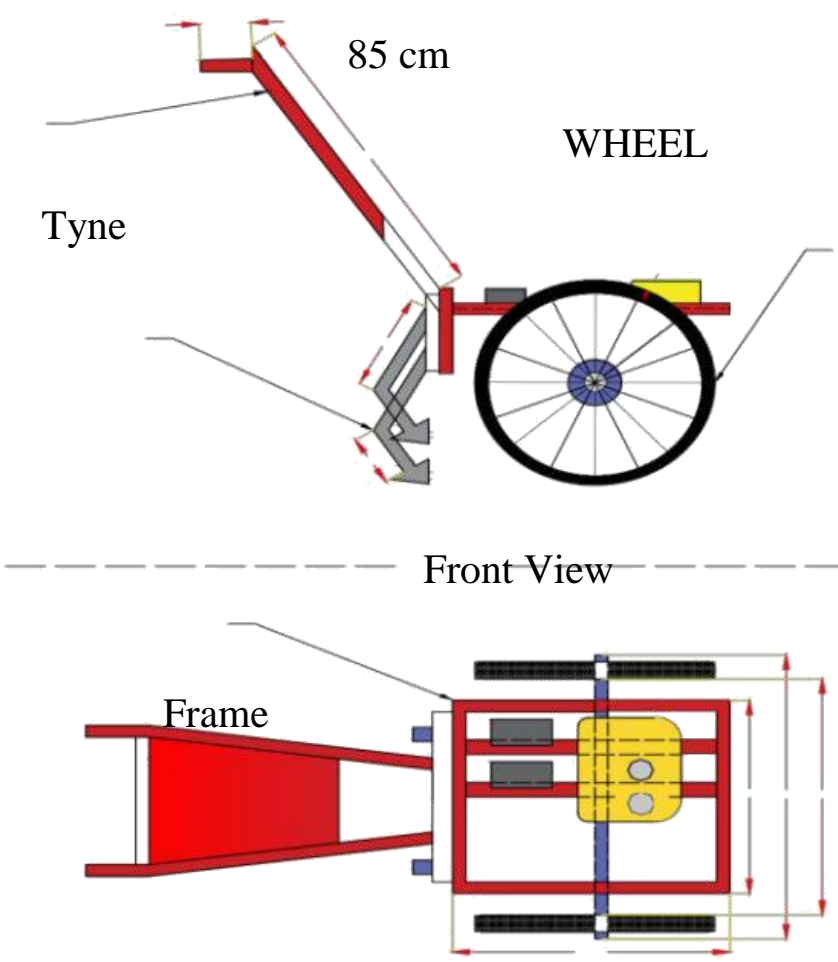

Top View

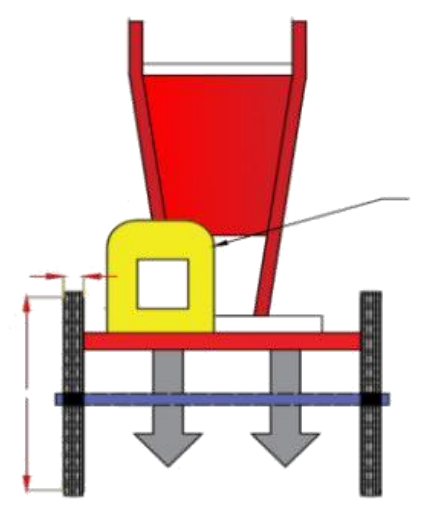

Fig.1 Dsign of developed rotary power weeder 


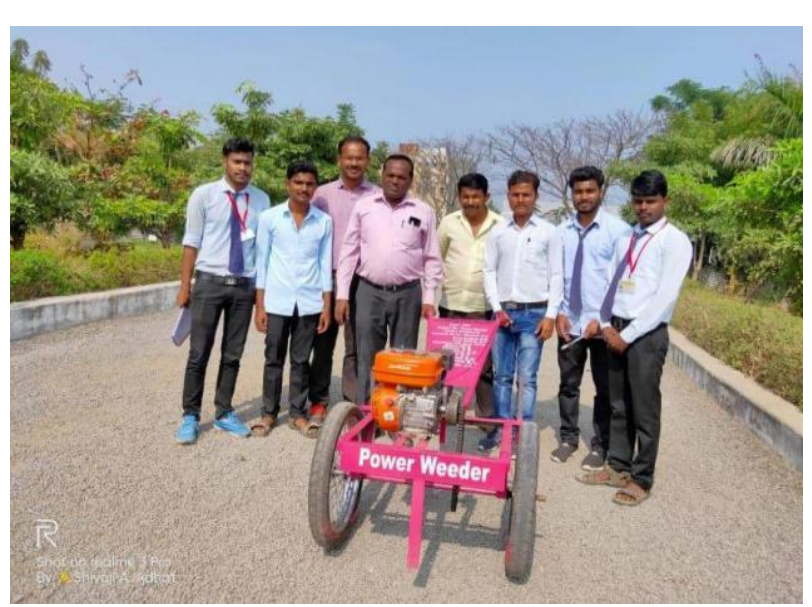

Fig.2 Developed power weeder

Chain length,

The length of the chain is given by

$\mathrm{Lp}=\frac{2 \quad 36+(14+44)}{2}+\frac{[(44-14)]^{2 / 36}}{2}$

$\mathrm{LP}=72+36+1.2$

$\mathrm{Lp}==109.2$ pitches

$\mathrm{Lp}=110$ Pitches (appro.)

Design of Chain length

Speed of wheel shaft calculated by following equation, (Sharma, 2013).

$$
11=22
$$

$\mathrm{N} 1=$ Speed of engine. $(400 \mathrm{rpm})$

$1=$ No of teeth on engine sprocket. (14 Teeth)

$\mathrm{N} 2=$ Speed of wheel shaft.

$2=$ No of teeth on wheel shaft. (44 teeth)

$$
\frac{400 \quad 14}{44}
$$

Speed of wheel shaft $=2.15 \mathrm{~m} / \mathrm{s}$
Therefore speed of wheel shaft was considered $2.15 \mathrm{~m} / \mathrm{s}$.

\section{Power unit}

The power for rotary weeder used for weeding operation was calculated as $2.5 \mathrm{hp}$ with all major factors taken into account as speed, soil resistance etc. Hence, a single cylinder, 2- stroke petrol engine of $2.5 \mathrm{hp}$, air cooled engine was used in power weeder. The technical specifications of the engine are shown in Table.1.

Table.1 Technical specification of the Engine

\begin{tabular}{|l|l|l|}
\hline $\begin{array}{l}\text { Sr. } \\
\text { No. }\end{array}$ & Particulars & Specification \\
\hline 1 & Type & $\begin{array}{l}\text { Air cooled, } \\
\text { 2 stroke, } \\
\text { Horizontal Spark } \\
\text { ignition engine }\end{array}$ \\
\hline 2 & Fuel & Petrol engine \\
\hline 3 & $\begin{array}{l}\text { Fuel tank } \\
\text { capacity }\end{array}$ & 3.5 \\
\hline 4 & Starting & Recoil start \\
\hline 5 & Engine weight & $17 \mathrm{~kg}$ \\
\hline 6 & $\begin{array}{l}\text { Recommended } \\
\text { speed }\end{array}$ & $400 \mathrm{~m}$ \\
\hline
\end{tabular}

\section{Performance parameter}

\section{Weeding efficiency}

Weeding efficiency can be calculated by following equation (Tajuddin, 2006)

$(\%)=1-21$

Where,

W1 $=$ Number of Weeds counted before weeding operation

$\mathrm{W} 2=$ Number of Weeds counted after weeding operation. 


\section{Plant damage}

Plant damage can be calculated by following equation (Tajuddin, 2006)

$(\%)=1-$

Where, $\mathrm{q}=$ Number of plants in $10 \mathrm{~m}$ row length of field before weeding $\mathrm{p}=$ Number of plants in $10 \mathrm{~m}$ row length of field after weeding

\section{Field Efficiency}

Field Efficiency can be calculated by following equation (Tajuddin, 2006)

Field efficiency (\%)

Where,

$\mathrm{AFC}=$ Actual field capacity, ha/h

$\mathrm{TFC}=$ Theoretical field capacity, ha/h

\section{Field capacity}

Field capacity (ha/h) was computed by recording the area weeded during each trial run in a given time interval. With the help of stopwatch, time was recorded for respective trial run along with area covered. Field capacity calculated by equation (Tajuddin, 2006).
Actual field capacity $(\mathrm{AFC})=10$

$h=10$

Where

$\mathrm{S}=$ speed of travel, $\mathrm{Kmph}$,

$\mathrm{W}=$ theoretical width of cut of the implement, $\mathrm{m}$,

$E=$ field efficiency in percent.

\section{Results and Discussion}

\section{Performance parameter}

\section{Weeding efficiency:}

The developed power weeder was operated in field at speed of $1.5 \mathrm{~m} / \mathrm{s}, 2 \mathrm{~m} / \mathrm{s}$ and $2.5 \mathrm{~m} / \mathrm{s}$. The weeding efficiency was decreased from $70.5 \%$ to $63.87 \%$ at speed from $1.5 \mathrm{~m} / \mathrm{s}$ to 2 $\mathrm{m} / \mathrm{s}$, because at higher speed the operation of power weeder was difficult in field.

The weeding efficiency decreased from 63.87 to $52.70 \%$ because at higher speed weeder operation was difficult in field and also at higher speed operation in row crop to proceeds towards plant damage. Hence speed of weeder considered at $1.5 \mathrm{~m} / \mathrm{s}$ as an optimized parameter. Weeding efficiency as shown in table. 2 .

Table.2 Weeding efficiency and field efficiency

\begin{tabular}{|c|c|c|c|c|}
\hline $\begin{array}{c}\text { Sr. } \\
\text { No }\end{array}$ & $\begin{array}{c}\text { Speed of } \\
\text { operation, } \\
(\mathrm{m} / \mathrm{s})\end{array}$ & $\begin{array}{c}\text { Weeding } \\
\text { Efficiency } \\
(\%)\end{array}$ & $\begin{array}{c}\text { Plant } \\
\text { Damage } \\
(\%)\end{array}$ & $\begin{array}{c}\text { Field Efficiency } \\
(\%)\end{array}$ \\
\hline 1 & 1.5 & 70.50 & 3.2 & 75 \\
\hline 2 & 2 & 63.87 & 6 & 65 \\
\hline 3 & 2.5 & 52.70 & 7.5 & 63 \\
\hline
\end{tabular}

\section{Plant Damage}

Plant damage at speed of $1.5 \mathrm{~m} / \mathrm{s}, 2 \mathrm{~m} / \mathrm{s}$, and $2.5 \mathrm{~m} / \mathrm{s}$ was $3.2,6$ and 7.5 , respectively. The plant damage was increased from speed of 1.5 $\mathrm{m} / \mathrm{s}$ to $2 \mathrm{~m} / \mathrm{s}$ because weeder was difficult to operate in field and also problem of handling weeder in row crop. At $1.5 \mathrm{~m} / \mathrm{s}$ the Weeding efficiency was highest and plant damage was lowest. So, Speed of operatio1.5 m/s 
considered as optimized parameter.

\section{Field efficiency}

Developed power weeder was operated in field at speed of $1.5 \mathrm{~m} / \mathrm{s}, 2 \mathrm{~m} / \mathrm{s}, 2.5 \mathrm{~m} / \mathrm{s}$. The field efficiency decreased from $75 \%$ to $65 \%$ at speed from 1.5 to $2 \mathrm{~m} / \mathrm{s}$, because at higher speed operation of weeder was difficult in field. Also field efficiency decreased from 65 to $63 \%$ because at higher speed operation was difficult in filed and balancing of rotary weeder was difficult in row crop. Hence speed of weeder considered at $1.5 \mathrm{~m} / \mathrm{s}$ as an optimized parameter. Field efficiency as shown in table 4.1.

\section{Fuel consumption}

The fuel consumption of developed rotary power weeder was 0.70 to $0.90 \mathrm{l} / \mathrm{h}$. The average fuel consumption of rotary weeder was $0.8 \mathrm{l} / \mathrm{h}$.

\section{References}

Bhosale, R., A. Herkar, A. Herkar, N. Shinde, Design and Fabrication of Agricultural Rotary Weeder, International Journal of Scientific Research in Science, Engineering and Technology, 3(2), 2017, 2394-4099.

Goel, A.K., D. Behera, B.K.Behera, S.K.Mohanty, S.K.Nanda, Development and Ergonomic Evaluation of Manually Operated Weeder for Dry Land Crops, Agricultural Engineering International: the CIGR Ejournal,Volume X, 2008.

Rajvir Yadav and Sahastrarashmi Pund, Development and Ergonomic Evaluation of Manual Weeder, Agricultural Engineering International: The CIGR e-journal, Volume (9), 2007.

Sailas o. (2015). Development and Evaluation of Wheeled Long-Handle Weeder, The West Indian Journal of Engineering, 37(2), 2015, 37-44.

Sharma, D., and S. Mukesh, 2013, Farm machinery design princuples and problem. Jain Brothers.

Sirmour, A. and A. Verma, Design and development of single row power weeder for rice, Journal of Crop and Weed, 14(1), 2018, 163-169.

Tajuddin, A., Design, development and testing of engine operated weeder, Agricultural Engineering Today, 30(5, 6). 2006. 25-29.

\section{How to cite this article:}

Gatkal Narayan Raosaheb, A.P. Petkar and Bhutada. S.H. 2020. Design and Development of Rotary Power Weeder. Int.J.Curr.Microbiol.App.Sci. 9(02): 1063-1068. doi: https://doi.org/10.20546/ijcmas.2020.902.124 